\title{
A SYNOPSIS OF THE APHID TRIBE PTEROCOMMINI.
}

By H. F. Wir.son,

Entomologist, Oregon Agricultural College.

As in all other groups of the Hemipterous family Aphidida the species grouped under the tribe name Pterocommini have been greatly mixed by different writers and as a result much confusion exists. In this paper the writer hopes to eliminate at least a part of this.

All the known species commonly feed on willows and poplars; one species is recorded as also being found on maple. Three species ( $P$. salicis, populea and flocculosum) are recorded from Europe and five from America ( $P$. populea, smithice, flocculosum, bicolor and salicis). The writer has never found the last nor has he seen specimens collected in this country. In all ten species have been described as follows:

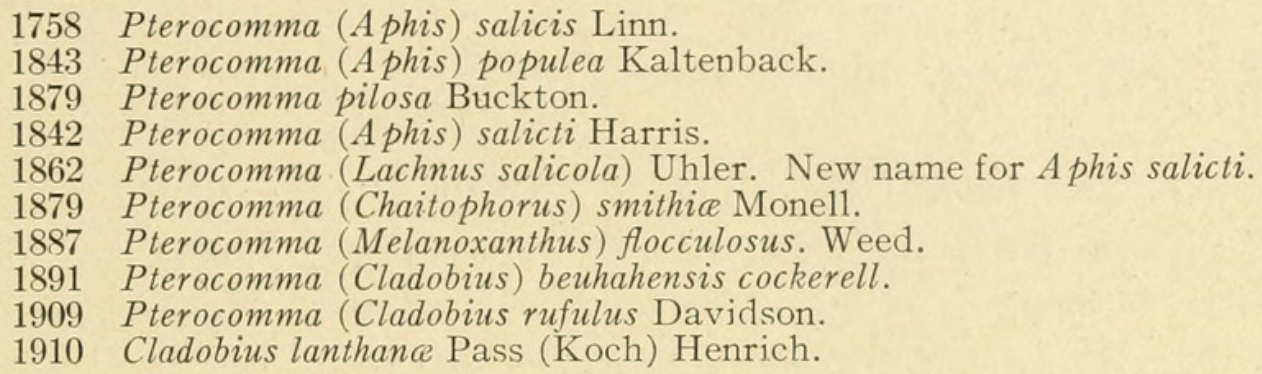

\section{Generic Synonomy.}

Aphidologists in general have divided the species of this tribe into two groups based as a rule upon the structure of the nectaries, although Buckton erected the genus Pterocomma for his species $P$. pilosa on what he thought was a peculiar wing structure. (Pergande ${ }^{30}$ believes this apparent character due to a fold in the wing.) Those species having swollen nectaries have been placed in one genus and those having cylindrical nectaries were placed in another. Such a distinction was also made by the writer in 1909, but after having further studied the group I am of the opinion that such a division is illogical and if a division is necessary each species should form a different genus. It, therefore, seems more practical to confine all the species to a single genus.

The genus name Cladobius found by Koch, 1857, was previously used in Coleoptera, 1837. Passerini, 1860, suggested a new name, Aphioides, but the writer believes that this is a 
contraction or misprint of $A$ phidioides which was also previously used in the Hemiptera and must, therefore, give way to Pterocomma, provided by Buckton for his species pilosa, and which the writer believes is the same as Aphis populea Kalt. Previous to the establishment of this genus Buckton used Melanoxanthus to cover Aphis salicis of Linnæus and this name would be valid if it had not already been used in the Coleoptera. Schouteden 1906 uses Melanoxantherium in place of Melanoxanthus, but the writer is of the opinion that Melanoxanthus falls before Pterocomma. Kirkaldy ${ }^{16}$ provides the name Aristaphis in place of Cladobius and Aphioides, apparently considering these names to be preoccupied.

The synonomy of the genus would then read:

Pterocomma Buckton.

A phioides Passerini.

Cladobius Koch.

Melanoxanthus Buckton.

Melanoxantherium Schout.

Aristaphis Kirkaldy.

\section{Characters of the tribe and genus.}

Antennæ with six segments and reaching to near the base of the abdomen. Wings normally with venation as in Aphis. Nectaries short, but clavate. Cauda short and broadly rounded at the tip as in Lachnini. Entire body, antennæ and legs, covered with long hairs as in the Lachnini. As has already been pointed out by Oestlund, this group appears intermediate between the Chaitophorini and the Lachnini. Their habits and actions being in different ways similar to both.

A Key to the Species.*

1. Nectaries with diameter of opening at tip not greater than the smallest part of the nectary

2. Nectaries with diameter of opening at tip greater than the smallest part of the nectary.

3. Distal end of nectaries abruptly constricted to a small opening; flange wanting

P. flocculosa

Distal end of nectaries not abruptly constricted. Nectary swollen in the middle and tapering to a small opening at the tip. Light flange present.

P. salicis

4. Nectaries short and stout, length not more than twice the greatest diameter

Nectaries more than twice as long as the greatest diameter.

5. Nectaries clavate and twice as long as the hind tarsi.

P. smithiæ hind tarsi.

P. bicolor

*Prof. C. P. Gillette, of the Colorado Agricultural College, kindly assisted in the preparation of this key. 

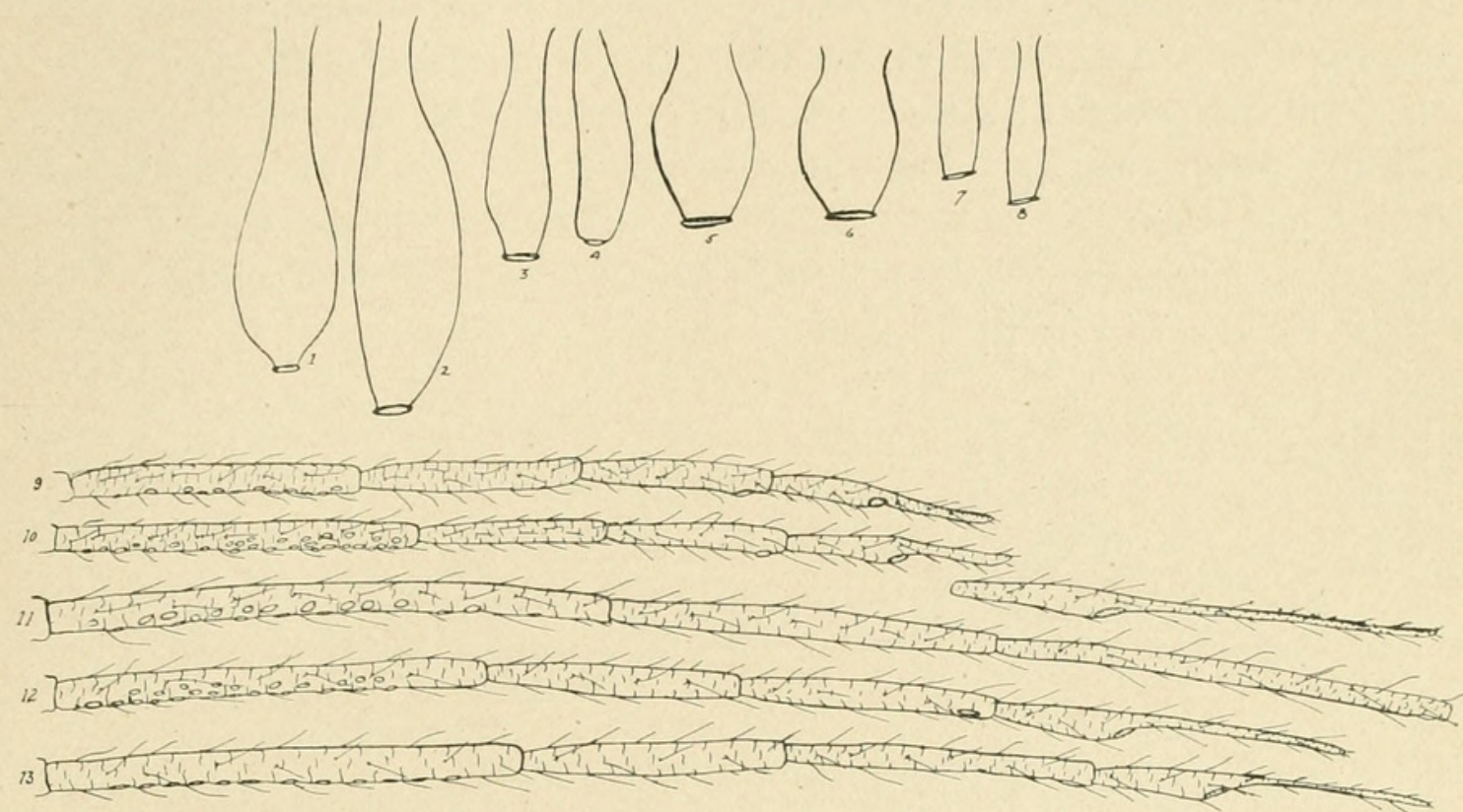

Figure 1, Nectary of $P$. salicis; Figure 2, Nectary of form found in U. S. (bicolor? salicis?) possibly new. Figure 3 , Nectary of $P$. bicolor; Figure 4, Nectary of $P$. flocculosa; Figures 5 and 6 , Nectaries of $P$. smithice; Figures 7 and 8 , Nectaries of $P$. populea; Figure 9, antennæ of $P$. smitihce; Figure 10, antennæ of $P$. populea; Figure 11, antennæ of $P$. flocculosa; Figure 12, antennæ of $P$. bicolor; Figure 13, $P$. salicis.

\section{Pterocomma salicis Linn.}

Synonomy: Aphis salicis, Linn. Reaum., Fabr., Schrank, De Geer, Kalt.

Melanoxanthus salicis Linn (Buckton).

? Melanoxanthus salicis Linn (Weed).

? Melanoxanthus salicis Linn (Packard).

? Melanoxanthus salicis Linn (Osborn).

? Melanoxanthus salicis Linn (Cowen).

Melanoxantherium salicis Linn (Schouteden).

? Melanoxantherium salicis Linn (Gillette).

Melanoxantherium salicis Linn (Wilson).

Since this species does not seem to occur in America it is not possible to secure a description from live material. A detailed description of what appears to be this species is given by Kaltenback and Buckton, figures accompanying the latter. Buckton's description is included here with additional notes made by myself from material on slides and in alcohol.

A pterous viviparous female.

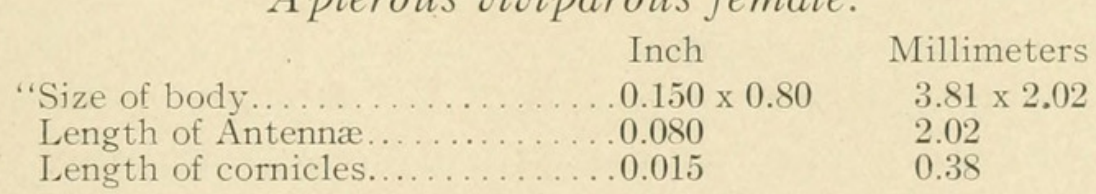


"Very large, long oval, abdomen pointed. Dull sootyblack or greyish black, with a faint greyish medial stripe. Prothorax with a blunt tooth-like process on each side. Two broad pale grey patches on each side of the first abdominal ring - smaller patches on each side of the succeeding rings, those at and below the insertions of the cornicles being the largest. Antennæ orange red. The seventh joint small, hardly equal to the sixth. The cornicles bright orange, skittle-shaped, with dilated mouths; very short. Legs orange, with dark tibial joints and tarsi. The whole insect pilose. The underside is of obscure greyish-green. Rostrum long, reaching to the third coxæ. The young insects are black and prettily streaked with grey. Their rostra are longer than those of the adult."

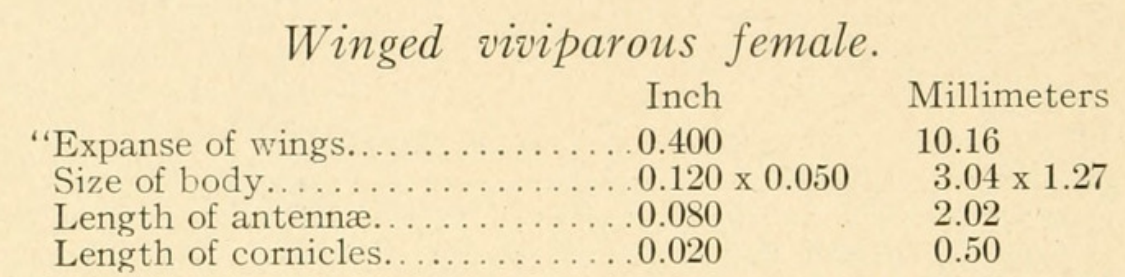

"Very large, greyish black, pilose. Antennæ short, having all joints black except the third and fourth, which are orange. Abdomen with two or more grey dorsal patches. Cornicles bright orange. Legs as in the larvæ. Eyes dark brown. Wings ample." "All veins are black and strongly marked."

The writer finds that the antennæ reach to the middle of the abdomen and that the third segment is the longest. From 14 to 20 round sensoria, irregularly placed on the inner side, occur on the third segment. The wings have dark veins as indicated, but hardly appear different from those of other species. The nectaries are the distinguishing characteristic as they are quite distinct in shape. See drawings.

\section{Pterocomma flocculosa (Weed) ${ }^{38}$.}

Synonomy:

Melanoxantherium flocculosus (Weed) ${ }^{33} \mathrm{a},{ }^{34}$.

Melanoxantherium flocculosum (Weed) Schouteden.

Melanoxantherium flocculosum (Weed) Gillette.

That this species commonly occurs in Europe is shown by the fact that the writer has received specimens both from Russia and France, and Schouteden has recorded it from Belgium. 
This species has never been collected by myself and it apparently does not occur on the Pacific Coast. For this reason color notes are taken from the original descriptions and the additional notes were made from specimens collected in Colorado and Maryland and mounted on slides.

"Oviparous Female.-Body 3-5 mm. long by 2 wide across middle of abdomen; antennæ $2-3 \mathrm{~mm}$. long.

"General color dull, yellowish-brown, with a longitudinal row of indistinct black spots on each side of dorso meson; cornicles bright orange red, anteninæ dusky, except basal portion of third joint, which is yellowish brown; legs dusky, with basal portion of femora, and sometimes more or less of tibia, dark yellowish-brown. Body, legs, and antennæ pilose; Joint III of antennæ long, but shorter than IV plus V, which are subequal; VI and VII each rather long, the latter the longer of the two. Cornicles long for this genus; swollen in the middle.

"The Egg.-Length, 1-2 mm.; oblong oval, coated with a thin gray substance like that on the egg of M. salicis; deposited on the bark, about the buds and axils, especially where the surface is roughened. Later he also describes what he believes to be the wingless male."

Apterous viviparous female: As a rule among the species of this group the apterous forms are almost exactly alike except in size and one would expect this form to resemble very closely in color markings, the oviparous female. Observations made from a slide containing several apparently apterous forms show the third antennal segment with about 14 round sensoria lying in a more or less regular line along the inside edge. In the alate form there are from 17 to 25 on the third segment. Along each side of the body may be found, one to each segment, a row of the thick short tubercles. Nectaries long and swollen, but sides tapering gradually and not suddenly bulged as in $P$. salicis. Opening at tip small and apparently without a flange. Entire body and legs covered with long hair.

Measurements and Length of Body. $-3.6 \mathrm{~mm}$.; width $1.5 \mathrm{~mm}$. Length of antennal segments, III, $0.75 \mathrm{~mm}$; IV, $0.51 \mathrm{~mm}$; $\mathrm{V}, 0.5 \mathrm{~mm}$.; VI, $0.22 \mathrm{~mm}$.; spur $0.28 \mathrm{~mm}$. Total length $2.65 \mathrm{~mm}$. Length of nectaries, $0.4 \mathrm{~mm}$. 
Alate viviparous female: Body large, broadly ovate, antennæ reaching the center of the abdomen. Antennæ rather slender and with the third segment bearing from 17 to 25 round sensoria along the inner side. Wings normal, veins clear. Abdomen probably with dentate tubercles on sides, but not visable on specimens at hand. Nectaries of shape indicated in drawings.

Measurements: Length of body, $3.28 \mathrm{~mm}$; width across abdomen, $1.5 \mathrm{~mm}$. Length of antennal segments, III, 0.79 mm.; IV, $0.51 \mathrm{~mm}$.; V, $0.62 \mathrm{~mm}$.; VI, $0.26 \mathrm{~mm}$; spur, $0.43 \mathrm{~mm}$. Length of nectaries, $0.4 \mathrm{~mm}$. Length of wing, $4.64 \mathrm{~mm}$.

\section{Pterocomma bicolor (Oestlund).}

Synonomy:

Melanoxanthus bicolor (Oestlund).

Melanoxanthus bicolor (Oest.) Weer.

? Melanoxanthus saiicis (Linn.) Weed.

? Melanoxanthus salicis (Linn) Packard.

? Melanoxanthus salicis (Linn) Osborn.

? Melanoxanthus salicis (Linn) Weed.

? Melanoxanthus salicis (Linn) Cowen.

Melanoxantherium salicis (Linn) Gillette.

In America there are two types of nectaries among the specimens designated as Melanoxantherium salicis Linn. One of these, as indicated in the accompanying drawings, the writer considers to be the one above indicated. For lack of proper evidence in rearing specimens the writer also considers the other type indicated as being a form of this species. However, later investigations may show the two to be from separate species. Certainly it is not Aphis salicis of Linn. for the writer has nineteen specimens of this group from France and Russia labeled Melanoxanthus salicis Linn. and the nectaries are quite distinct from any found on specimens collected in this country. It would seem then that the species Pterocomma salicis Linn. does not occur in America and the one or more species so determined are something else.

Alate viviparous female: General color, brownish, tinged with yellow. Antennæ with first two segments and the distal portions of 3 and 4 , opaque, bases of third and fourth lighter with a yellowish tinge, fifth and sixth segments black. Head and thorax shining dark brown. Abdomen reddish brown with the dorsal lobes with dusky patches and a light brown median line on the dorsum. Legs yellow at the base of each part and dusky towards the ends, tarsi black. Nectaries 
yellow with tips slightly dusky. Cauda black, entire body quite hairy and lightly covered with white powdery wax. Antennæ with from 20 to 25 round sensoria along the inner edge. The prothorax bears a single pair of dentate tubercles placed one on each side. Similar tubercles are also found on each segment of the abdomen. Wings with normal venation, nectaries about twice the length of the tarsi and swollen towards the ends. Just back of the flanged tip they are strongly constricted. Cauda broadly angular.

Measurements: Length of body $4.1 \mathrm{~mm}$; width $2.3 \mathrm{~mm}$. Length of Antennal segments, III, $0.6 \mathrm{~mm}$.; IV, $0.36 \mathrm{~mm}$; $\mathrm{V}, 0.35 \mathrm{~mm}$.; sixth and spur, $0.5 \mathrm{~mm}$. Length of nectaries, $0.59 \mathrm{~mm}$.; Cauda, $0.34 \mathrm{~mm}$. Wing expanse, $9.89 \mathrm{~mm}$.

Apterous viviparous females: General color reddish brown, antennæ colored as in the alate form. Head chocolate brown and thoracic lobes slightly lighter, but darker than the abdomen. Abdomen with a series of dark spots or splotches on the dorsum and separated in the middle by a light brown median line. Similar spots may be found on the sides of the abdominal segments. A row of dentate tubercles occurs along side of the body, each abdominal segment and the prothorax having one on a side. Antennæ yellowish brown at the base and shading to black at the tip. Legs yellowish brown with the tips of the tibia and femora dusky. Tarsi black. Nectaries yellowish brown, slightly dusky at the tip. Cauda dusky brown and broadly angled.

Measurements: Length of body 3-7; width across abdomen, $1.71 \mathrm{~mm}$. Length of antennal segments, III, $0.61 \mathrm{~mm}$; IV, $0.285 \mathrm{~mm}$; V, $0.34 \mathrm{~mm}$.; VI, $0.9 \mathrm{~mm}$.; spur, 0.28. Total length, $1.88 \mathrm{~mm}$. Length of nectaries, $0.428 \mathrm{~mm}$.

\section{Pterocomma populea Kalt.}

Synonomy:

A phis populea Kaltenback.

Cladobius populeus (Kalt) Koch.

A phioides (Cladiobus) populeus Pass.

Pterocomma pilosa Buckton.

Cladobius populeus (Kalt.) Lichtenstein.

Cladobius populeus (Kalt.) Mordwilko 1-2-3.

Cladobius populeus (Kalt.) Del geurcio.

Cladobius populeus (Kalt.) Pergande.

Cladobius beulahensis Cockerell.

Cladobius populeus Henrich.

Cladobius rufulus Davidson.

Pterocomma pilosa (Buckton) Wilson.

Melanoxantherium rufulus (Davidson) Essig. 
Alate viviparous female: General color brown, but appearing grayish brown because of a covering of white waxy powder. Head brownish black, antennæ dusky to dark with the bases of the first to fourth segments opaque yellow or white. They extend to the base of the abdomen. Eyes red and rather prominent. Thorax shining amber to brownish black; wings normal; legs opaque brown. Prothorax with a single dentate tubercle on each side. Abdomen amber colored, grayish green below and dark brown above. Usually with a series of transverse bars on the dorsum broken down the center by a transverse white line. Also a series of black spots, one to each segment along the side and with a short stout tubercle in the center of each spot. Nectaries light opaque brown, dusky at the tip. Cauda yellowish-brown at base, dusky at tip. Body stout, abdomen broadly ovate. Antennæ reaching to base of abdomen, third segment along the outer edge. Wings normal with the median vein twice forked. Nectaries about as long as the tarsi and rather slender but swollen towards the tip. They are constricted just back of the tip, which is broadly flanged. Cauda short and angular. Entire body thickly set with black hairs.

Measurements: Length of body $3.7 \mathrm{~mm}$.; length of antennal segments III, $0.65 \mathrm{~mm}$; IV, $0.4 \mathrm{~mm}$; V, $0.4 \mathrm{~mm}$; VI and spur, $0.6 \mathrm{~mm}$. Total length $2.15 \mathrm{~mm}$. Length of nectaries, $0.39 \mathrm{~mm}$.; length of cauda, $0.4 \mathrm{~mm}$. Wing expanse, $9 . \mathrm{mm}$.

Apterous viviparous female: General color reddish-brown, but appearing more or less gray on account of the white waxy powder which covers the entire body, body oval, tapering towards the ends. Entire body covered with hairs. Above, the abdomen has a narrow white median line along the dorsum and a series of narrow transverse white lines which separate the segments. Along each side of the abdomen may also be found a series of black spots, one to each segment and in the center of each a denate tubercle. Antennæ with first two segments dusky or black; third segment opaque with a tinge of light brown, remaining segments shading from dusky to black toward the tip. Third segment without sensoria, fifth with one large near the distal end and sixth with one large and a series of small sensbria at the base of the spur. Legs with coxæ and base of femora light yellow, tibiæ and tarsi dark 
brown to black. Nectaries shorter than in the alate form and individuals taken at certain times of year with apparently cylindrical nectaries. The normal shape, however, is slightly swollen as seen in the illustration. Cauda short and broadly angular.

Measurements: Length of body, $3.3 \mathrm{~mm}$; width of abdomen, $1.7 \mathrm{~mm}$. Length of antennal segments, III, $0.53 \mathrm{~mm}$; IV, $0.35 \mathrm{~mm}$; $\mathrm{V}, 0.35 \mathrm{~mm}$; VI, with spur, $0.53 \mathrm{~mm}$. Total length, $1.92 \mathrm{~mm}$. Length of nectaries, $0.34 \mathrm{~mm}$.

The oviparous females resemble the Apterous viviparous forms so closely, except that they are larger that a separate description is not necessary. The males resemble the alate viviparous forms closely, but are much smaller. These two forms are quite common on the twigs and leaves of poplar along the streams of the Pacific Coast during October and November.

The eggs which are deposited about the base of the buds are green at first, later turning to a shining black. They are elongate oval in shape and measure about $1 \mathrm{~mm}$. in length.

Aphis salicis Harris.

A phis salicis Harris (Walsh).

Melanoxanthus salicis (Harris) Oestlund.

Melanoxanthus salicis (Harris) Weed.

Cladobius salicis (Harris) Davidson.

Cladobius salicis (Harris) Essig.

Lachnus salicicola Uhler, Thomas, Packard, Osborne.

The writer believes that on account of the short description given by Harris that this species is not valid and that the notes and records in most cases refer to Pterocomma smithice Monell.

In the third edition of Harris' "Insects of Mass." Uhler proposes to use Lachnus salicicola for Aphis salicti and from that date a number of writers have used that name.

\section{Pterocomma smithiæ Monnell.}

Synonomy:

? A phis salicti Harris.

Chaithoporus smithice Monell.

Chaitophorus smithice (Monel1) Thomas.

Melanoxanthus smithice (Monel1) Weed.

Melanoxantherium smithice (Monell) Gillette.

Melanoxantherium smithice (Mone11) Davis.

This is undoubtedly the same species as Aphis salicti Harris, but his description is too meager to determine the species 
with any degree of certainty and notes and records made under this name and under that of Lachnus solicicola Uhler could not have been based upon definite knowledge of the species in question. On the other hand, smithice is a definitely determined and well known species, the validity of which is unquestionable. It is commonly found on willow and poplar in Canada, Mexico and the United States. It has also been recorded from Maple by Weed, and I have specimens in my collection from privet hedge, Santa Crux, Mexico, by F. C. Bishop.

Apterous viviparous female: General color black and brownish-yellow, but all specimens have a bluish-black appearance because of the whitish powder found covering the body. Antennæ dusky at base, third and lower half of fourth segments yellow; remaining proportions dusky to black. Legs with coxæ femora and basal two-thirds of tibiæ brown, outer portion of tibiæ and tarsi black. Nectaries yellow. Antennæ shorter than in other species of the group and more nearly like those of the Lachnince. Apparently without sensoria on the third segment. Abdomen with a row of broad short tubercles along each side. Nectaries short, swollen in the middle and contracted at both ends. Opening widely flanged. Cauda short and broadly rounded.

Measurements: Length of body, $2.8 \mathrm{~mm}$; width, $1-5 \mathrm{~mm}$.; length of antennal segments, III, $0.5 \mathrm{~mm}$; IV, $0.28 \mathrm{~mm}$; $\mathrm{V}, 0.26 \mathrm{~mm}$.; VI, $0.14 \mathrm{~mm}$; spur, $0.18 \mathrm{~mm}$. Total length, $1.5 \mathrm{~mm}$. Length of nectaries, $0.26 \mathrm{~mm}$.

Alate viviparous female: General color black and brownishyellow, but appearing bluish on account of the white waxy covering found over the entire body. Antennæ with two basal segments dusky-black. Third segment yellowish at base and dusky toward tip, remaining segments dusky to black. Legs with coxæ, femora and basal half of tibiæ yellow; remaining portion or tibia and tarsi black. Wing venation normal, veins slightly darkened. Nectaries yellow, tinged with brown. Cauda black. Antennæ extending slightly beyond the third pair of legs, and third segment bearing from 19 to 26 circular sensoria irregularly placed along the inner side. Thorax and abdomen with a row of thick short tubercles along each side. Nectaries short, swollen in the middle and strongly 
constricted at both ends. Opening at tip large and widely flanged. Cauda short and broadly rounded.

Measurements: Length of body, $3 \mathrm{~mm}$; width, $1.2 \mathrm{~mm}$. Length of antennal segment, III, $0.44 \mathrm{~mm}$.; IV, $0.26 \mathrm{~mm}$; $\mathrm{V}, 0.27 \mathrm{~mm}$; VI, $0.14 \mathrm{~mm}$; spur, $0.14 \mathrm{~mm}$. Total length of antennæ, $1.42 \mathrm{~mm}$. Length of nectaries, $0.3 \mathrm{~mm}$. Length of wing, $4.7 \mathrm{~mm}$.

\section{Cladobius lanthanice (Pass) Koch (Henrich).}

Henrich lists Aphis lantance Koch under the above name and refers it to Passerini. The writer has never seen this species, but from the description given by Koch and his figures I am of the opinion that it does not belong here.

$\mathrm{He}$ also records a species under the name of Cladobius ? salicis $(\mathrm{m})$ from trauerweide (Weeping Willow).

\section{BIBLIOGRAPHY.}

1. 1879 -Buckton, G. B., Mon. Brit. Aphids, II pp. 21-23 and 142-144 Fig.

2. 1904 -Cockerell, T. D. A., Canadian Ent. XXXVI, p. 263.

3. 1895 - Cowen, J. H., Col. Agr. Col. Ex. Sta. Bull. 31, p. 117.

4. 1909 -Davidson, W. M., Jour. Econ. Ent. II, p. 414.

5. 1910 -Davidson, W. M., Jour. ibid III, p. 375.

6. 1910 -Davis, J. J., Jour. Econ. Ent. III, p. 414.

7. 1911-Davis, J. J., Univ. of Nebraska Studies, XI, No. 3, p. 7 Figs.

8. 1773 -De Geer.

9. 1900 -Del. Guercio, G., Nouve Relaz. R. Staz. Ent. Agraria. Florence Italy, Ser. 1. No. 2, p. 120.

10. 1911-Essig, E. O., Pomona Jour. Ent. III. No. 2, p. 46.

11. 1912-Essig, E. O., ibid IV, No. 3, pp. 786 and 827.

12. 1794-1803-Fabricius, J. C., several citations but not sufficient description to designate the species.

13. 1909 - Gillette, C. P., Jour. Econ. Ent. II, p. 385.

14. 1910 Henrich C., Die Blattlause Aphididae Emgebund von Hermannstadt, p. 55 .

15. 1843-Kaltenback, J. H., Monographic der Pflanzenlause.

16. 1905 -Kirkaldy, G. W., Canadian Ent. Vol. XXXVII. p. 415.

17. 1857-Koch, C. L., Die Pflanzenlause Aphiden p. 252.

18. 1884 Lichtenstein, J., La Flore Aphidiens. Montpelier.

19. 1879 -Monell, J. T., U. S. Geol. Surv. Bull. V., p. 200.

20. 1894-95-Mordwilko, A., Rab. Lab. Zool. Kab. Warsaw. Vol.?

21. 1908 -Mordwilko, A., Ann. Rept. Imperial Acad. Sci. St. Petersburg.

22. 1914 Mordwilko, A., Fauna Russia and Limitrophic Countries. Zool. Mus. Acad. Imp. Sci. Petrograd.

23. 1758-89-Linnæus, C., Systemæ Naturæ. 10th edition (Notes of small value).

24. 1886 -Oestlund, O. W., Geol. Nat. Hist. Surv. Minn. p. 52.

25. 1887-Oestlund, O. W., Geol.-Nat. Hist. Surv. Bull. 4 pp. 35-36.

26. 1892 - Osborn, H., Cat. Hem. Ia. p. 129.

27. 1890 -Packard, A. S., U. S. Ent. Comm. 5th Rept. p. 592.

28. 1860 -Passerini, G. Gliafidi, Pomona p. 28.

29. 1863 -Passerini, G. Gliafidi, Aphididæ Italicæ, p.? 
30. 1900 - Pergande, Theo., Prac. Acad. Sci. Wash. II, p. 516.

31.? 17-Reaumur, III, pl. 22, Fig. 2.

32. 1898 -Rubsaamen, Bibl. Zool. XX. p.?

33. 1801-Schrank, Fauna Boica II, p. 102.

33a. 1900 -Schouteden, H., Ann. Soc. Ent. Gelg. XLIV, p. 128.

34. 1906 - Schouteden, H., Ann. Soc. Ent. Belg. I.

35. 1879 - Thomas, C., Eight Rept. State Ent. III. p. 200.

36. 1889-Weed, C. M., Psyche V, 208-209.

37. $1890-W e e d$, C. M., Ohio Agr. Exp. Sta. Bull. Tec. Ser. I. No. 2. Fig.

38. 1891-Weed, C. M., Insect Life III, 290-292.

39. 1893 -Weed, C. M., Trans. Amer. Ent. Soc. XX, p. 300.

40. 1861-Walsh, B. D., Prac. Ent. Soc. Phil. I. p. 298.

41. 1891-Williams, T. A., Dept. of Ent. Univ. of Nebraska sp. Bull. 1.

42. 1911-Williams, T. A., The Aphid Neb. Univ. Studies X, No. 2, p. 34.

43. 1910-Wilson, H. F., Canadian Ent. XLII, p. 384.

44. 1915-Wilson, H. F., Proceedings Ent. Soc. British Columbia, No. 5, N. S. p. 84 . 


\section{$2 \mathrm{BHL}$ Biodiversity Heritage Library}

Wilson, H. F. 1915. "A Synopsis of the Aphid Tribe Pterocommini." Annals of the Entomological Society of America 8, 347-358.

https://doi.org/10.1093/aesa/8.4.347.

View This Item Online: https://www.biodiversitylibrary.org/item/43631

DOI: https://doi.org/10.1093/aesa/8.4.347

Permalink: https://www.biodiversitylibrary.org/partpdf/193778

\section{Holding Institution}

Smithsonian Libraries

\section{Sponsored by}

Smithsonian

\section{Copyright \& Reuse}

Copyright Status: NOT_IN_COPYRIGHT

This document was created from content at the Biodiversity Heritage Library, the world's largest open access digital library for biodiversity literature and archives. Visit BHL at https://www.biodiversitylibrary.org. 